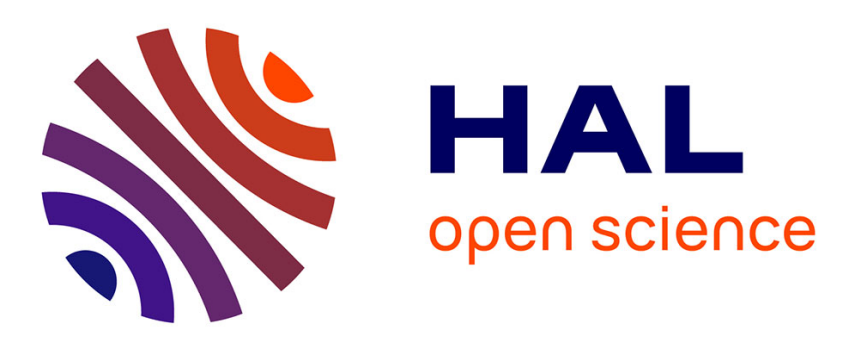

\title{
Non-susceptibility to tigecycline in enterococci from hospitalised patients, food products and community sources
}

Ana R. Freitas, Carla Novais, Rosa Correia, Márcia Monteiro, Teresa M. Coque, Luísa Peixe

\section{To cite this version:}

Ana R. Freitas, Carla Novais, Rosa Correia, Márcia Monteiro, Teresa M. Coque, et al.. Nonsusceptibility to tigecycline in enterococci from hospitalised patients, food products and community sources. International Journal of Antimicrobial Agents, 2011, 10.1016/j.ijantimicag.2011.04.014 . hal-00711301

\section{HAL Id: hal-00711301 https://hal.science/hal-00711301}

Submitted on 23 Jun 2012

HAL is a multi-disciplinary open access archive for the deposit and dissemination of scientific research documents, whether they are published or not. The documents may come from teaching and research institutions in France or abroad, or from public or private research centers.
L'archive ouverte pluridisciplinaire $\mathbf{H A L}$, est destinée au dépôt et à la diffusion de documents scientifiques de niveau recherche, publiés ou non, émanant des établissements d'enseignement et de recherche français ou étrangers, des laboratoires publics ou privés. 


\section{Accepted Manuscript}

Title: Non-susceptibility to tigecycline in enterococci from hospitalised patients, food products and community sources

Authors: Ana R. Freitas, Carla Novais, Rosa Correia, Márcia Monteiro, Teresa M. Coque, Luísa Peixe

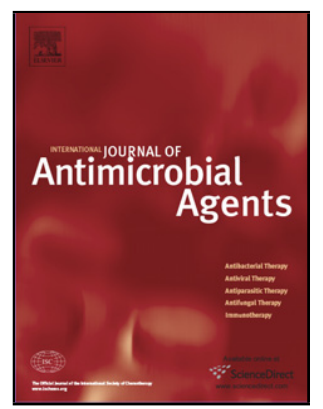

PII:

S0924-8579(11)00215-9

DOI: doi:10.1016/j.ijantimicag.2011.04.014

Reference: ANTAGE 3617

To appear in: International Journal of Antimicrobial Agents

Received date:

23-2-2011

Revised date:

$30-3-2011$

Accepted date:

$18-4-2011$

Please cite this article as: Freitas AR, Novais C, Correia R, Monteiro M, Coque TM, Peixe L, Non-susceptibility to tigecycline in enterococci from hospitalised patients, food products and community sources, International Journal of Antimicrobial Agents (2010), doi:10.1016/j.jjantimicag.2011.04.014

This is a PDF file of an unedited manuscript that has been accepted for publication. As a service to our customers we are providing this early version of the manuscript. The manuscript will undergo copyediting, typesetting, and review of the resulting proof before it is published in its final form. Please note that during the production process errors may be discovered which could affect the content, and all legal disclaimers that apply to the journal pertain. 


\section{Non-susceptibility to tigecycline in enterococci from hospitalised patients, food products and community sources}

Ana R. Freitas ${ }^{a, b}$, Carla Novais ${ }^{a, c}$, Rosa Correia ${ }^{a}$, Márcia Monteiro a , Teresa M. Coque $^{\mathrm{b}, \mathrm{d}, \mathrm{e}}$, Luísa Peixe ${ }^{\mathrm{a}, \star}$

${ }^{a}$ REQUIMTE, Laboratório de Microbiologia, Faculdade de Farmácia, Universidade do Porto, Rua Aníbal Cunha 164, 4050-047 Porto, Portugal

${ }^{\text {b }}$ Fundación para la Investigación en Biomédica del Hospital Universitario Ramón y Cajal (FiBioHRYC, IRYCIS), Madrid, Spain

' Faculdade Ciências da Saúde, Universidade Fernando Pessoa, Porto, Portugal

${ }^{d}$ CIBER en Epidemiología y Salud Pública (CIBERESP), Spain

e Unidad de Resistencia a Antibióticos y Virulencia Bacteriana Asociada al Consejo Superior de Investigaciones Científicas (CSIC), Madrid, Spain

ARTICLE INFO

Article history:

Received 23 February 2011

Accepted 18 April 2011

Keywords:

Enterococcus

Hospitals

Healthy humans

Animals 
Tigecycline

Tetracycline

* Corresponding author. Tel.: +351 22207 8946; fax: +351 222003977.

E-mail address: Ipeixe@ff.up.pt (L. Peixe). 


\section{ABSTRACT}

In this study, the in vitro activity of tigecycline against 1140 enterococci collected from humans, food products, animals and the environment in Portugal (1996-2008) was analysed. Ten isolates (seven Enterococcus faecalis and three Enterococcus spp.) non-susceptible to tigecycline (minimum inhibitory concentrations of $0.5-1.0$ $\mathrm{mg} / \mathrm{L})$, which were also resistant to tetracycline and minocycline, were mostly observed in samples collected before the introduction of tigecycline in the therapeutic arsenal. The E. faecalis isolates were recovered from hospitalised patients ( $n=2$; ST319/CC2 and ST34), healthy humans ( $n=2 ;$ ST21/CC21), chicken meat ( $n=1$; ST260) as well as from two swine samples. The remaining isolates were also recovered from chicken meat ( $n=1$; Enterococcus gallinarum) and swine ( $n=2$; Enterococcus hirae and Enterococcus spp.). Recovery of enterococcal isolates with reduced susceptibility to tigecycline among different reservoirs, including animals for food consumption, suggests that selection of tigecycline-resistant isolates by antibiotics other than tigecycline might occur in nonclinical settings. 


\section{Introduction}

The most clinically relevant Gram-positive pathogens, i.e. meticillin-resistant Staphylococcus aureus (MRSA), vancomycin-resistant enterococci (VRE) and multidrug-resistant (MDR) pneumococci, have increasingly acquired resistance to most antimicrobial agents, making the nosocomial infections they cause difficult to treat [1]. Against this background, there is a clear need for therapeutic alternatives.

Glycylcyclines are novel tetracycline analogues with improved ribosomal binding-site affinity that show activity against a broad spectrum of bacteria, including those resistant to tetracycline $[2,3]$. Tigecycline (9-t-butylglycylamido-minocycline), the first glycylcycline approved for clinical use by the US Food and Drug Administration (FDA) in 2005 and registered by the European Medicines Agency in May 2006, is recommended to treat complicated skin and intra-abdominal infections caused by several Gram-negative and Gram-positive organisms, including MDR Enterococcus faecalis and Enterococcus faecium. The World Health Organization (WHO) has recently highlighted the relevance of tigecycline as one of the last therapeutic options in several human infections [4]. A few resistant $E$. faecalis isolates showing minimum inhibitory concentrations (MICs) close to the epidemiological cut-off value (ECOFF) for this antibiotic have been reported in large clinical trials, although the mechanism of resistance remains to be characterised $[5,6]$.

To our knowledge, the activity of tigecycline against enterococcal isolates recovered from the community has not previously been studied. Moreover, there are no data regarding the activity of this antibiotic against enterococcal isolates from Portugal, one of the countries with the highest prevalence of VRE (http://www.earss.rivm.nl). 
The aim of this study was to evaluate the in vitro activity of tigecycline, an antibiotic of last resort to treat severe human infections, against enterococci from different sources.

\section{Methods}

A total of 1140 enterococcal isolates collected during 1996-2008 were studied, most of which have been included in previous studies by our group [7]. The isolates were recovered from the following sources: (i) 294 clinical isolates from different patients at six hospitals in different cities in northwestern, central and eastern Portugal (1996-2008); (ii) 208 isolates from faecal samples of healthy human volunteers living in the north and centre of the country (2001-2004); (iii) 288 isolates from swine faeces and environmental samples recovered in six piggeries and one slaughterhouse from the north, centre and south of Portugal (1997-2007); (iv) 234 isolates from raw poultry products corresponding to 93 chicken lots and 6 turkey lots from ten different commercial brands and purchased at two different butcher shops in the Porto area (1999-2001); and (v) 116 isolates from hospitals wastewaters and from the estuary of the Douro River in Porto city (2001-2003).

Clonal relatedness was established in specific cases by pulsed-field gel electrophoresis (PFGE) and multilocus sequence typing (MLST) as described elsewhere (http://www.mlst.net) [7]. Species identification and vancomycin and tetracycline resistance gene detection were performed by multiplex polymerase chain reaction (PCR) assays [8]. 
Susceptibility testing was performed by the standard agar dilution or disk diffusion methods following Clinical and Laboratory Standards Institute (CLSI) guidelines [9]. For tigecycline (Wyeth Pharmaceuticals, Havant, UK), cation-adjusted MuellerHinton II agar (bioMérieux, Marcy-l'Étoile, France) was always freshly prepared and the antibiotic was incorporated into the media a few hours prior to use to avoid oxidation [10]. When borderline to resistance MIC values were obtained, susceptibility assays were repeated five times to evaluate the reproducibility of the results. Staphylococcus aureus ATCC 29213 and E. faecalis ATCC 29212 were used as controls for susceptibility tests. The susceptibility breakpoint value was determined according to the European Committee on Antimicrobial Susceptibility Testing (EUCAST), which establishes clinical criteria for interpretation of tigecycline activity in enterococci (susceptible $\leq 0.25 \mathrm{mg} / \mathrm{L}$ and resistant $>0.5 \mathrm{mg} / \mathrm{L}$ )

(http://www.eucast.org; last update January 2011). This committee also recommends an ECOFF (MIC $\leq 0.25 \mathrm{mg} / \mathrm{L}$ ) to detect enterococci expressing acquired resistance mechanisms to tigecycline (http://217.70.33.99/Eucast2/SearchController) [11]. According to these guidelines, isolates showing MICs $\geq 0.5 \mathrm{mg} / \mathrm{L}$ were considered non-susceptible to tigecycline.

\section{Results}

Among 294 clinical isolates and 846 non-clinical isolates, enterococci were identified as E. faecium $(n=485)$, E. faecalis $(n=405)$ and Enterococcus spp. $(n=250)$. In total, 884 isolates $(78 \%)$ were resistant to three or more antibiotics from different groups, 796 isolates $(70 \%)$ showed resistance to tetracycline and 270 isolates $(24 \%)$ were resistant to vancomycin ( $83 \%$ vanA, $16 \%$ vanC1 and $1 \%$ vanB). Most studied isolates (>99\%) were susceptible to tigecycline, showing MICs ranging from $\leq 0.03$ 
$\mathrm{mg} / \mathrm{L}$ to $0.25 \mathrm{mg} / \mathrm{L}$ (Table 1 ). In agreement with other studies, the median $\mathrm{MIC}_{50}$ and $\mathrm{MIC}_{90}$ values (MICs for $50 \%$ and $90 \%$ of the organisms) for enterococci from different origins were $0.125 \mathrm{mg} / \mathrm{L}$ and $0.25 \mathrm{mg} / \mathrm{L}$, respectively [12,13]. Moreover, $E$. faecalis isolates showed higher $\mathrm{MIC}_{50}$ values than $E$. faecium and Enterococcus spp. isolates $(0.25 \mathrm{mg} / \mathrm{L}$ vs. $0.125 \mathrm{mg} / \mathrm{L})$ as previously reported [13,14]. A difference in tigecycline activity was not observed in isolates from different sources or with different antibiotic resistance phenotypes.

Ten tetracycline-resistant isolates recovered from hospitalised and non-hospitalised humans, food products and animals (7 E. faecalis, 1 Enterococcus hirae, 1 E. gallinarum and 1 Enterococcus spp.; MICs $32 \mathrm{mg} / \mathrm{L}$ to $>256 \mathrm{mg} / \mathrm{L}$ ) were also resistant to minocycline (MICs 32-64 $\mathrm{mg} / \mathrm{L}$ ) and showed non-susceptibility to tigecycline, with MICs ranging from $0.5 \mathrm{mg} / \mathrm{L}(n=7$, of which 3 contained tetM and 1 contained tetM + tetL) to $1 \mathrm{mg} / \mathrm{L}(n=3 ; 2$ tetM (Table 2$)$. Enterococcus faecalis were obtained from: (i) hospitalised patients [ $n=2$ isolates recovered in 2002; the new sequence type 319 (ST319) belonging to clonal complex 2 (CC2) and ST34]; (ii) healthy humans ( $n=2$ isolates from 2001; same PFGE type identified as ST21/CC21); (iii) chicken meat ( $n=1$; ST260 from 1999); and (iv) swine ( $n=2$ isolates from 2006-2007; not typed by MLST). The remaining enterococcal isolates (1999-2007) were recovered from chicken meat (1 E. gallinarum) and swine (1 E. hirae and 1 Enterococcus spp.). Previous studies have also described a few $E$. faecalis clinical isolates exhibiting MICs against tigecycline of $0.5 \mathrm{mg} / \mathrm{L}[6,12,15]$ and $1 \mathrm{mg} / \mathrm{L}$ (by broth microdilution) [5]. 


\section{Discussion}

To our knowledge, the only enterococcal isolate showing an MIC value against tigecycline higher than the EUCAST clinical breakpoint was a clinical German E. faecalis strain belonging to the prevalent ST6 (CC2) from which resistance was associated with antibiotic treatment comprising multiple courses of different drugs besides tigecycline [5]. In this study, we report the lack of susceptibility to tigecycline among E. faecalis from hospitalised patients, healthy humans, chicken meat and swine mainly collected before the introduction of tigecycline in clinical practice. The data suggest that a selection process of tigecycline-resistant isolates might occur in non-clinical settings involving antibiotics other than tigecycline.

\section{Acknowledgments}

Tigecycline powder was freely provided by Wyeth-Pfizer (Portugal).

\section{Funding}

ARF was supported by fellowships from Fundação para a Ciência e Tecnologia (FCT) from Portugal (SFRH/BD/24604/2005). Research on enterococci was supported by grants from the Seven Framework Program of the European Union (LSHE-2007-037410) and from the Ministry of Science and Innovation from Spain (PI 07/1441, PS09/02381).

\section{Competing interests}

None declared.

\section{Ethical approval}


Not required. 


\section{References}

[1] Garrison MW, Nuemiller JJ. In vitro activity of tigecycline against quinoloneresistant Streptococcus pneumoniae, methicillin-resistant Staphylococcus aureus and vancomycin-resistant enterococci. Int J Antimicrob Agents 2007;29:191-6.

[2] Borbone S, Lupo A, Mezzatesta ML, Campanile F, Santagati M, Stefani S. Evaluation of the in vitro activity of tigecycline against multiresistant Grampositive cocci containing tetracycline resistance determinants. Int J Antimicrob Agents 2008;31:209-15.

[3] Peterson LR. A review of tigecycline-the first glycylcycline. Int J Antimicrob Agents 2008;32(Suppl 4):S215-22.

[4] Collignon P, Powers JH, Chiller TM, Aidara-Kane A, Aarestrup FM. World Health Organization ranking of antimicrobials according to their importance in human medicine: a critical step for developing risk management strategies for the use of antimicrobials in food production animals. Clin Infect Dis 2009;49:132-41.

[5] Werner G, Gfrörer S, Fleige C, Witte W, Klare I. Tigecycline-resistant Enterococcus faecalis strain isolated from a German intensive care unit patient. J Antimicrob Chemother 2008;61:1182-3.

[6] Tubau F, Liñares J, Rodríguez MD, Cercenado E, Aldea MJ, González-Romo F, et al. Susceptibility to tigecycline of isolates from samples collected in hospitalized patients with secondary peritonitis undergoing surgery. Diagn Microbiol Infect Dis 2010;66:308-13.

[7] Novais C, Freitas AR, Sousa JC, Baquero F, Coque TM, Peixe LV. Diversity of Tn1546 and its role in the dissemination of vancomycin resistance in Portugal. Antimicrob Agents Chemother 2008;52:1001-8. 
[8] Dukta-Malen S, Evers S, Courvalin P. Detection of glycopeptide resistance genotypes and identification to the species level of clinically relevant enterococci by PCR. J Clin Microbiol 1995;33:24-7.

[9] Clinical and Laboratory Standards Institute. Performance standards for antimicrobial susceptibility testing; twentieth informational supplement. Document M100-S20. Wayne, PA: CLSI; 2010.

[10] Bradford PA, Petersen PJ, Young M, Jones CH, Tischler M, O'Connell J. Tigecycline MIC testing by broth dilution requires use of fresh medium or addition of the biocatalytic oxygen-reducing reagent oxyrase to standardize the test method. Antimicrob Agents Chemother 2005;49:3903-9.

[11] European Committee on Antimicrobial Susceptibility Testing (EUCAST) Steering Committee. EUCAST technical note on tigecycline. Clin Microbiol Infect 2006;12:1147-9.

[12] Brown SD, Traczewski MM. Comparative in vitro antimicrobial activity of tigecycline, a new glycylcycline compound, in freshly prepared medium and quality control. J Clin Microbiol 2007;45:2173-9.

[13] Betriu C, Rodríguez-Avial I, Sánchez BA, Gómez M, Alvarez J, Picazo JJ; Spanish Group of Tigecycline. In vitro activities of tigecycline (GAR-936) against recently isolated clinical bacteria in Spain. Antimicrob Agents Chemother 2002;46:892-5.

[14] Nørskov-Lauritsen N, Marchandin H, Dowzicky MJ. Antimicrobial susceptibility of tigecycline and comparators against bacterial isolates collected as part of the TEST study in Europe (2004-2007). Int J Antimicrob Agents 2009;34:121-30.

[15] Waites KB, Dufy LB, Dowzicky MJ. Antimicrobial susceptibility among pathogens collected from hospitalized patients in the United States and in vitro 
activity of tigecycline, a new glycylcycline antimicrobial. Antimicrob Agents Chemother 2006;50:3479-84. 


\section{Table 1}

In vitro activity of tigecycline against enterococci isolated from different species and sources

\begin{tabular}{|c|c|c|c|c|c|c|c|c|c|c|}
\hline \multirow[t]{3}{*}{ Species } & \multirow[t]{3}{*}{ Source } & \multirow[t]{3}{*}{ Type } & \multirow{3}{*}{$\begin{array}{l}\text { No. of isolates } \\
\text { tested }\end{array}$} & \multirow{2}{*}{\multicolumn{5}{|c|}{$\begin{array}{l}\text { No. of isolates inhibited at tigecycline } \\
\text { MIC ( } \mathrm{mg} / \mathrm{L} \text { ) of: }{ }^{a}\end{array}$}} & \multirow{3}{*}{$\begin{array}{l}\mathrm{MIC}_{50} \\
(\mathrm{mg} / \mathrm{L})\end{array}$} & \multirow{3}{*}{$\begin{array}{l}\mathrm{MIC}_{90} \\
(\mathrm{mg} / \mathrm{L})\end{array}$} \\
\hline & & & & & & & & & & \\
\hline & & & & $\leq 0.03$ & 0.0625 & 0.125 & 0.25 & 0.51 .0 & & \\
\hline Enterococcus faecalis & ATCC 29212 & \multicolumn{2}{|c|}{ Control b $^{b}$} & & $\mathrm{X}$ & $\mathrm{X}$ & & & & \\
\hline Staphylococcus aureus & ATCC 29213 & \multicolumn{2}{|c|}{ Control $^{\mathrm{b}}$} & & & $x$ & $x$ & & & \\
\hline \multirow{10}{*}{$\begin{array}{l}\text { Enterococcus faecium ( } n \\
=485)\end{array}$} & \multirow{2}{*}{$\begin{array}{l}\text { Hospitalised } \\
\text { patients }\end{array}$} & \multirow{2}{*}{$\begin{array}{l}\text { VRE } \\
\text { VSE }\end{array}$} & 112 & 2 & 36 & 49 & 25 & & 0.125 & 0.25 \\
\hline & & & 18 & & 5 & 10 & 3 & & 0.125 & 0.25 \\
\hline & \multirow[t]{2}{*}{ Healthy humans } & VRE & 6 & & 1 & 3 & 2 & & 0.125 & 0.25 \\
\hline & & VSE & 80 & 3 & 23 & 42 & 12 & & 0.125 & 0.25 \\
\hline & \multirow[t]{2}{*}{ Swine } & VRE & 7 & & 2 & 4 & 1 & & 0.125 & 0.25 \\
\hline & & VSE & 98 & 1 & 17 & 50 & 30 & & 0.125 & 0.25 \\
\hline & \multirow{2}{*}{ Poultry } & VRE & 46 & 3 & 4 & 26 & 13 & & 0.125 & 0.25 \\
\hline & & VSE & 42 & 1 & 7 & 23 & 11 & & 0.125 & 0.25 \\
\hline & \multirow[t]{2}{*}{ Environment } & VRE & 26 & & 9 & 15 & 2 & & 0.125 & 0.25 \\
\hline & & VSE & 50 & 1 & 12 & 23 & 14 & & 0.125 & 0.25 \\
\hline \multirow[t]{3}{*}{ E. faecalis $(n=405)$} & \multirow{2}{*}{$\begin{array}{l}\text { Hospitalised } \\
\text { patients }\end{array}$} & VRE & 37 & & 5 & 15 & 17 & & 0.125 & 0.25 \\
\hline & & VSE & 123 & 2 & 20 & 38 & 61 & 2 & 0.25 & 0.25 \\
\hline & Healthy humans & VRE & 0 & & & & & & & \\
\hline
\end{tabular}




\begin{tabular}{|c|c|c|c|c|c|c|c|c|c|c|c|}
\hline & & VSE & 100 & 1 & 7 & 24 & 66 & 1 & 1 & 0.25 & 0.25 \\
\hline & \multirow[t]{2}{*}{ Swine } & VRE & 1 & & & & 1 & & & N/D & $N / D$ \\
\hline & & VSE & 52 & 2 & 3 & 8 & 37 & 2 & & 0.25 & 0.25 \\
\hline & \multirow[t]{2}{*}{ Poultry } & VRE & 5 & 1 & & 2 & 2 & & & N/D & $N / D$ \\
\hline & & VSE & 59 & 1 & 1 & 21 & 35 & 1 & & 0.25 & 0.25 \\
\hline & \multirow[t]{2}{*}{ Environment } & VRE & 3 & & 1 & 2 & & & & $N / D$ & $\mathrm{~N} / \mathrm{D}$ \\
\hline & & VSE & 25 & & 5 & 12 & 8 & & & 0.125 & 0.25 \\
\hline \multirow{10}{*}{$\begin{array}{l}\text { Enterococcus spp. }(n= \\
250)\end{array}$} & Hospitalised & VRE & 2 & & & 2 & & & & $N / D$ & $N / D$ \\
\hline & patients & VSE & 2 & & & 2 & & & & N/D & $N / D$ \\
\hline & Healthy humans & VRE & 0 & & & & & & & & \\
\hline & & VSE & 22 & & 3 & 9 & 10 & & & 0.125 & 0.25 \\
\hline & Swine & VRE & 0 & & & & & & & & \\
\hline & & VSE & 130 & 4 & 10 & 53 & 61 & $1^{c}$ & $1^{d}$ & 0.125 & 0.25 \\
\hline & Poultry & VRE & 25 & & 5 & 12 & 8 & & & 0.125 & 0.25 \\
\hline & 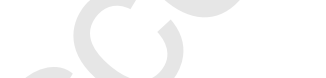 & VSE & 57 & 3 & 9 & 28 & 16 & & $1^{e}$ & 0.125 & 0.25 \\
\hline & Environment & VRE & 0 & & & & & & & & \\
\hline & & VSE & 12 & & 3 & 7 & 2 & & & 0.125 & 0.25 \\
\hline
\end{tabular}

MIC, minimum inhibitory concentration; $\mathrm{MIC}_{50 / 90}$, MIC for $50 \%$ and $90 \%$ of the organisms, respectively; VRE, vancomycin-resistant enterococci; VSE, vancomycin-susceptible enterococci; N/D, not determined due to the small number of isolates.

${ }^{a}$ Numbers in bold correspond to the 10 isolates showing MIC values of $0.5-1.0 \mathrm{mg} / \mathrm{L}$ (non-susceptibility). 
$\mathrm{b}$ The MICs of tigecycline varied between $0.125 \mathrm{mg} / \mathrm{L}$ and $0.25 \mathrm{mg} / \mathrm{L}$ for $\mathrm{S}$. aureus ATCC 29213 and $0.06 \mathrm{mg} / \mathrm{L}$ and $0.125 \mathrm{mg} / \mathrm{L}$ for E. faecalis ATCC 29212 control strains, which is consistent with data reported by other groups [5,12].

${ }^{\mathrm{c}}$ Swine isolate identified as Enterococcus hirae.

${ }^{d}$ Swine isolate that could not be identified by the multiplex polymerase chain reaction (PCR) assays used, which includes $E$. faecium, E. faecalis, Enterococcus gallinarum, Enterococcus casseliflavus, E. hirae and Enterococcus durans.

${ }^{\text {e }}$ Poultry isolate identified as E. gallinarum. 


\section{Table 2}

Features of tigecycline-non-susceptible Enterococcus isolates

\begin{tabular}{|c|c|c|c|c|c|c|c|c|c|c|c|c|}
\hline \multirow[t]{2}{*}{ Species } & \multirow[t]{2}{*}{ Source } & \multirow[t]{2}{*}{ Year } & \multirow[t]{2}{*}{ PFGE } & \multirow[t]{2}{*}{ MLST } & \multirow[t]{2}{*}{$t^{2} t^{\mathrm{a}}$} & \multicolumn{7}{|c|}{$\begin{array}{l}\text { Antibiotic resistance profiles }[\mathrm{MIC}(\mu \mathrm{g} / \mathrm{mL}) \text { or } \\
\mathrm{S} / \mathrm{R}]\end{array}$} \\
\hline & & & & & & TIG & TET & MIN & ERY & CIP & STR & GEN \\
\hline E. faecalis & Healthy human & 2001 & A & ST21 (CC21) & M & 1 & 64 & 64 & $\mathrm{~S}$ & $\mathrm{~S}$ & $\mathrm{R}$ & $\mathrm{S}$ \\
\hline E. faecalis & Chicken retail product & 1999 & B & ST260 (CS) & M & 0.5 & 64 & 64 & $\mathrm{~S}$ & $\mathrm{~S}$ & $\mathrm{~S}$ & $\mathrm{~S}$ \\
\hline E. faecalis & $\begin{array}{l}\text { Piggery } 1 \text { (liquid } \\
\text { manure) }\end{array}$ & 2007 & $N / D$ & $N / D$ & - & 0.5 & $>256$ & 64 & $\mathrm{R}$ & $\mathrm{S}$ & $\mathrm{R}$ & $\mathrm{S}$ \\
\hline E. faecalis & Hospitalised patient & 2002 & C & $\underset{b}{\text { ST319 (CC2) }}$ & - & 0.5 & $>256$ & 64 & $\mathrm{R}$ & $S$ & $\mathrm{R}$ & $S$ \\
\hline E. hirae & $\begin{array}{l}\text { Piggery } 1 \text { (solid } \\
\text { manure) }\end{array}$ & 2006 & $N / D$ & $\mathrm{~N} / \mathrm{A}$ & $\mathrm{M}$ & 0.5 & $>256$ & 32 & $\mathrm{~S}$ & $\mathrm{~S}$ & $\mathrm{~S}$ & $\mathrm{~S}$ \\
\hline $\begin{array}{l}\text { Enterococcus } \\
\text { spp. }\end{array}$ & $\begin{array}{l}\text { Piggery } 2 \text { (liquid } \\
\text { manure) }\end{array}$ & 2007 & $N / D$ & $\mathrm{~N} / \mathrm{A}$ & - & 1 & 64 & 32 & $S$ & $\mathrm{R}$ & $S$ & $S$ \\
\hline
\end{tabular}


PFGE, pulsed-field gel electrophoresis; MLST, multilocus sequence typing; MIC, minimum inhibitory concentration; S, susceptible; R, resistant; TIG, tigecycline; TET, tetracycline; MIN, minocycline; ERY, erythromycin; CIP, ciprofloxacin; STR, high-level resistance to streptomycin; GEN, high-level resistance to gentamicin; ST, sequence type; CC, clonal complex; CS, singleton; N/D, not determined; N/A, not applicable.

${ }^{a}$ tet genes sought by polymerase chain reaction $(\mathrm{PCR})$ included tetM, tetL, tetO, tetK, tetS and tet $X$.

${ }^{b}$ ST319 is a novel sequence type clustering in CC2 by eBURST analysis. 